\title{
Tumor necrosis factor-alpha promoter polymorphism 308 G/A is not significantly associated with esophageal cancer risk: a meta-analysis
}

\author{
Ming Luo ${ }^{1, *}$, Yuan Yang 2,*, Dongmei Luo ${ }^{3, *}$, Liang Liu ${ }^{4, *}$, Yuening Zhang ${ }^{5}$, Feifan \\ $\mathrm{Xiao}^{5}$, Jingcheng Yang ${ }^{2}$, Chengdong Zhang ${ }^{1,2,6,7}$, Shen Fu' ${ }^{6,7}$, Zhiguo Luo ${ }^{1}$ \\ ${ }^{1}$ Department of Clinical Oncology, Taihe Hospital, Hubei University of Medicine, Shiyan, Hubei, China \\ ${ }^{2}$ School of Life Sciences, Fudan University, Shanghai, China \\ ${ }^{3}$ School of Mathematics and Physics, Anhui University of technology, Maanshan, Anhui, China \\ ${ }^{4}$ Department of Oncology, Fudan University Shanghai Cancer Center, Fudan University, Shanghai, China \\ ${ }^{5}$ Medical Scientific Research Center, Guangxi Medical University, Nanning, Guangxi, China \\ ${ }^{6}$ Department of Radiation Oncology, Shanghai Proton and Heavy Ion Center, Shanghai, China \\ ${ }^{7}$ Department of Radiation Oncology, Fudan University Shanghai Cancer Center, Shanghai, China \\ *These authors have contributed equally to this work and share first authorship \\ Correspondence to: Shen Fu, email: shen_fu@hotmail.com \\ Zhiguo Luo, email: oncology_group@163.com \\ Keywords: esophageal cancer, TNF-a-308 G/A, meta-analysis, risk, association
}

Received: June 06, $2016 \quad$ Accepted: October 21, $2016 \quad$ Published: November 04, 2016

\section{ABSTRACT}

Many studies have investigated the association between Tumor necrosis factor-a-308 G>A (rs1800629) and the risk of esophageal cancer. However, their results are inconsistent. Therefore, we performed a meta-analysis of available data to investigate any possible association between this polymorphism and esophageal cancer risk. We searched PubMed, EMBASE, Web of Science, and the CNKI database for articles published up to 2016. Crude and adjusted odds ratio with $95 \%$ confidence intervals were calculated using fixed or random effects models. We used a dominant model (GA+AA vs GG), a recessive model (AA vs GG+GA), an over-dominant model (GG+AA vs GA), and allele frequency ( $G$ vs $A$ ) to identify any association. Eleven studies with 5617 participants were included in the meta-analysis. Our results suggest that TNF-a-308 G>A (rs1800629) is not significantly associated with a risk of esophageal squamous cell carcinoma and esophageal adenocarcinoma. For genetic association studies, negative results of meta-analysis have a high level of evidence, and these results are important in this era of high-throughput sequencing-based precision medicine.

\section{INTRODUCTION}

Esophageal cancer (EC) which is the most common tumor of the digestive system has two major subtype: esophageal squamous cell carcinoma (ESCC) and esophageal adenocarcinoma (EAC) $[1,2]$. The survival rate of esophageal cancer is $<10 \%$ after five years [3], mainly because of its extremely aggressive nature and poor survival [4]. In 2016, an estimated 16,910 new esophageal cancer cases and 15,690 deaths occurred in United States [5].
Various factors can lead to EC: race, smoking, alcohol consumption, diet, nutrients, obesity and genetics [4]. However, we are still not familiar with the Genetic epidemiology. Some Genome-Wide Association Studies (GWAS) have shown that some single nucleotide polymorphisms (SNPs) are risk factors of EC $[1,6,7]$.

Tumor necrosis factor $\alpha$, as a central regular of inflammation, is a powerful pro-inflammatory cytokine $[8,9]$. Single nucleotide variation at 308 position of Tumor necrosis factor alpha (TNF $\alpha$, also known as TNF) has been proved to be altering the expression of TNF in 
transcriptional level $[10,11]$. Abnormal in the expression of TNF has been identified to be associated with major depression, Alzheimer's disease, psoriasis, inflammatory bowel disease and cancer [12-16].

Recently, some studies have focused on the association between TNF- $\alpha-308 \mathrm{G}>\mathrm{A}$ (rs1800629) and risk of EC. In 2003, Emad et al. found rs1800629 was not associated with risk of ESCC and EAC [17]. In 2010, Oh et al. did not observe association between rs1800629 and risk of ESCC and EAC [18], which was consistent with the findings of David et al [19]. In 2010, Zhang et al. and Zhao et al. suggested that there was no significantly association in ESCC $[20,21]$. Cui et al. found no association either in 2015 [22]. However, Umar et al. and Wang et al. showed association in 2013 and 2014 respectively [23, 24]. Due to the inclusive of the results. Here, we conducted a meta-analysis based on previously published studies to get a comprehensive result.

\section{RESULTS}

\section{Literature search}

A flow diagram for the study selection process is shown in Figure 1. In all, 334 articles were identified using the search strategy. Of these, 323 articles were excluded because they do not investigate the association between rs1800629 and risk of esophageal cancer and 11 articles were screened further. Of the 11 articles, 1 article was excluded because the genotype of the case-control group did not satisfy the Hardy-Weinberg Equilibrium (HWE), and 2 articles were excluded with the reason that their participants were same to the other. Finally, 8 publications with 11 case-control studies were included in the meta-analysis. The 8 publications comprised 6 English-language papers and 2 Chineselanguage papers.

\section{Study characteristics}

The primary characteristics of the 11 studies are summarized in Table 1. In all, 5617 participants (1855 cases and 3762 controls) were included in the metaanalysis. The studies were divided into 2 groups based on the type of esophageal cancer: 8 case-control studies involving ESCC and 3 case-control studies involving EAC. In order to reduce the influences of ethnicity on the result, we did subgroup analysis according to the ethnicity of their participants.

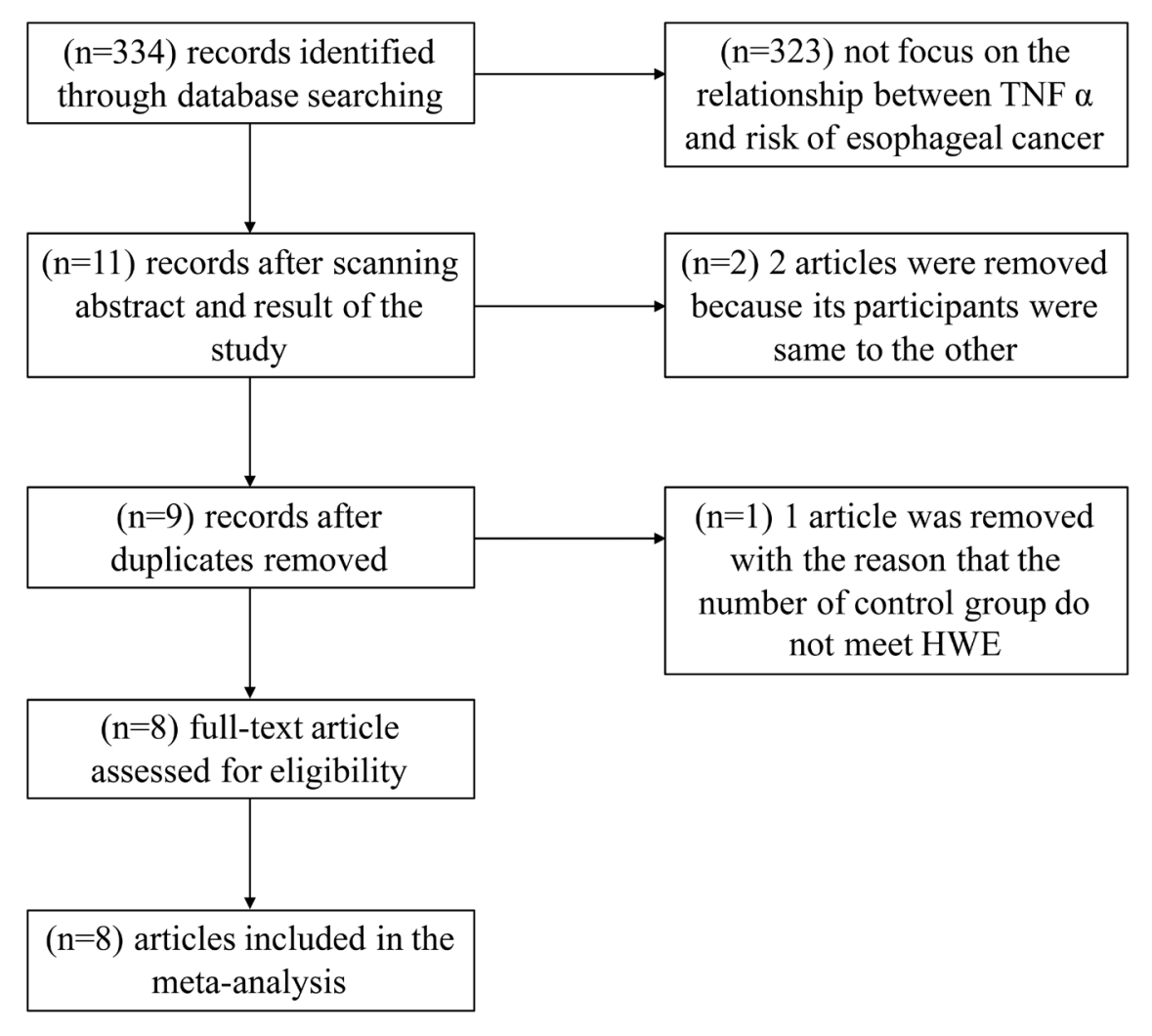

Figure 1: A flow diagram for the study selection process. In all, 334 articles were identified using the search strategy. Of these, 323 articles were excluded because they do not investigate the association between rs1800629 and risk of esophageal cancer and 11 articles were screened further. Of the 11 articles, 1 article was excluded because the genotype of the case-control group did not satisfy the Hardy-Weinberg Equilibrium (HWE), and 2 articles were excluded with the reason that their participants were same to the other. Finally, 8 publications with 11 case-control studies were included in the meta-analysis. 
Table 1: Characteristics of the 8 studies included in the meta-analysis

\begin{tabular}{|c|c|c|c|c|c|c|c|c|c|c|c|c|c|}
\hline \multirow{2}{*}{ Author } & \multirow{2}{*}{ Year } & \multirow{2}{*}{ Country } & \multirow{2}{*}{ Ethnicity } & \multirow{2}{*}{ Type $^{\mathrm{a}}$} & \multicolumn{3}{|c|}{ Cases } & \multicolumn{3}{|c|}{ Controls } & \multirow{2}{*}{$\begin{array}{c}P \text { value } \\
\text { of } \mathrm{HWE}^{\mathrm{b}}\end{array}$} & \multirow{2}{*}{ Susceptibility $^{\mathrm{c}}$} & \multirow{2}{*}{ Adjusted factor } \\
\hline & & & & & GG & GA & $\mathbf{A A}$ & GG & GA & $\mathbf{A A}$ & & & \\
\hline
\end{tabular}

Age, sex, BMI, smoking, alcohol, ethnicity, history of reflux symptoms, history of peptic

$\begin{array}{lllllllllllll}\begin{array}{l}\text { Emad } \\ \text { et al. }\end{array} & 2003 & \text { USA } & \text { Mix } & \text { ESCC } & 41 & 10 & 2 & 152 & 52 & 6 & 0.54823 & \end{array}$
u ulcer, family history of cancer, lauren classification, DNA source, and $\mathrm{H}$. pylori immunoglobulin G antibody

\begin{tabular}{|c|c|c|c|c|c|c|c|c|c|c|c|c|c|}
\hline $\begin{array}{l}\text { Oh } \\
\text { et al. }\end{array}$ & 2010 & $\begin{array}{l}\text { USA, } \\
\text { China }\end{array}$ & Mix & ESCC & 19 & 8 & 0 & 641 & 195 & 13 & 0.675274 & $\mathrm{~N}$ & $\begin{array}{l}\text { Age, sex, ethnicity, } \\
\text { education, smoking, } \\
\text { and alcohol }\end{array}$ \\
\hline $\begin{array}{l}\text { Zhang } \\
\text { et al. }\end{array}$ & 2010 & China & Han & ESCC & 99 & 19 & 2 & 82 & 12 & 1 & 0.466708 & $\mathrm{~N}$ & Age, and sex \\
\hline $\begin{array}{l}\text { David } \\
\text { et al. }\end{array}$ & 2010 & Australia & Caucasian & ESCC & 128 & 71 & 8 & 842 & 403 & 48 & 0.979478 & $\mathrm{~N}$ & $\begin{array}{l}\text { Age, sex, education, } \\
\text { BMI, smoking, } \\
\text { alcohol, frequency } \\
\text { of symptoms of } \\
\text { heartburn or reflux, } \\
\text { frequency of use } \\
\text { of aspirin/NSAIDs } \\
\text { past } 5 \text { years, and } \\
\text { self-reported prior H } \\
\text { pylori infection }\end{array}$ \\
\hline $\begin{array}{l}\text { Zhao } \\
\text { et al. }\end{array}$ & 2010 & China & Han & ESCC & 141 & 56 & 5 & 228 & 83 & 6 & 0.622221 & $\mathrm{~N}$ & Age, and sex \\
\hline
\end{tabular}

Age, sex, alcohol, ethnicity, tumor

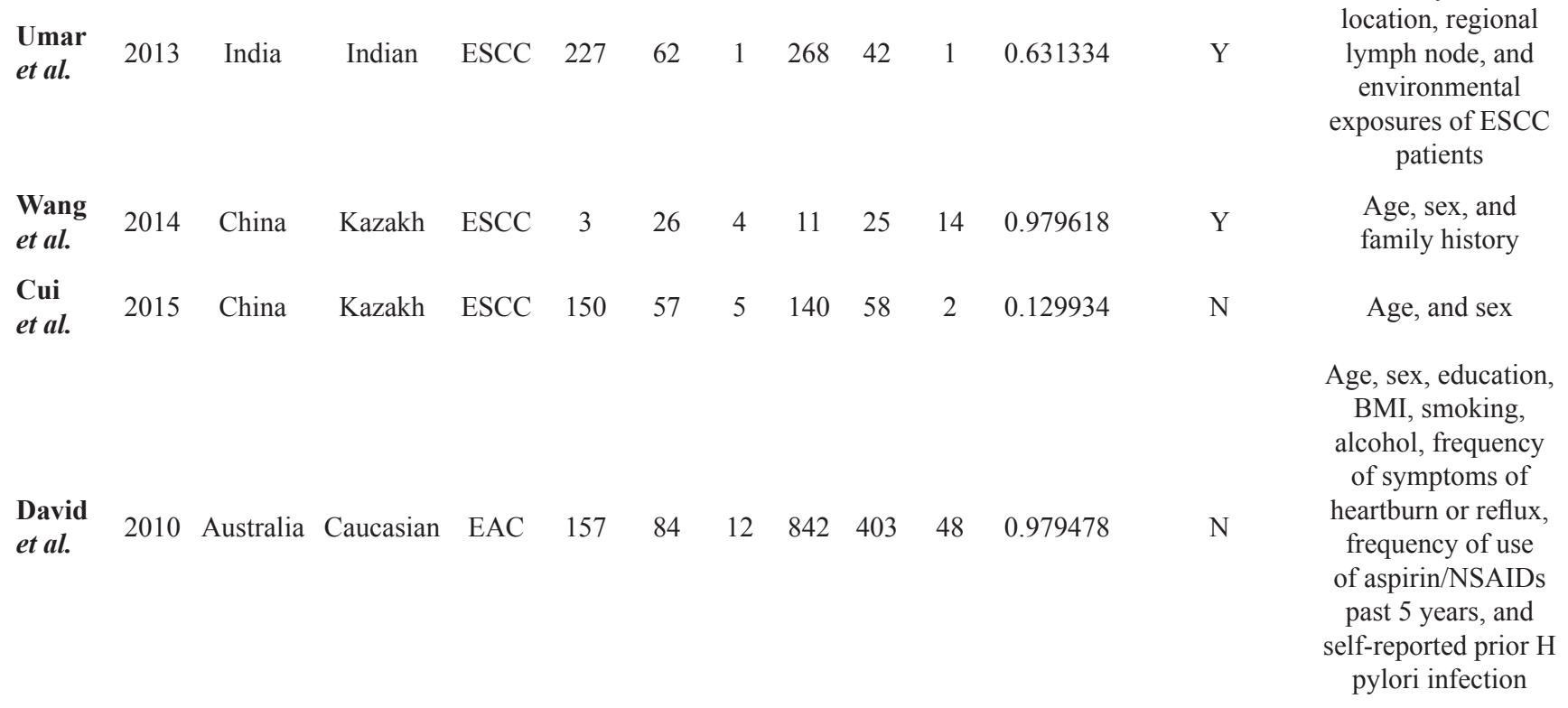

(Continued) 


\begin{tabular}{|c|c|c|c|c|c|c|c|c|c|c|c|c|c|}
\hline \multirow{2}{*}{ Author } & \multirow{2}{*}{ Year } & \multirow{2}{*}{ Country } & \multirow{2}{*}{ Ethnicity } & \multirow{2}{*}{ Type $^{a}$} & \multicolumn{3}{|c|}{ Cases } & \multicolumn{3}{|c|}{ Controls } & \multirow{2}{*}{$\begin{array}{c}P \text { value } \\
\text { of } \text { HWE }^{b}\end{array}$} & \multirow{2}{*}{ Susceptibility $^{\mathrm{c}}$} & \multirow{2}{*}{ Adjusted factors } \\
\hline & & & & & GG & GA & $\mathbf{A A}$ & GG & GA & $\mathbf{A A}$ & & & \\
\hline $\begin{array}{l}\text { Emad } \\
\text { et al. }\end{array}$ & 2003 & USA & Mix & EAC & 81 & 24 & 3 & 152 & 52 & 6 & 0.54823 & $\mathrm{~N}$ & $\begin{array}{l}\text { Age, sex, BMI, } \\
\text { smoking, alcohol, } \\
\text { ethnicity, history of } \\
\text { reflux symptoms, } \\
\text { history of peptic } \\
\text { ulcer, family history } \\
\text { of cancer, lauren } \\
\text { classification, } \\
\text { DNA source, } \\
\text { and H. pylori } \\
\text { immunoglobulin G } \\
\text { antibody }\end{array}$ \\
\hline $\begin{array}{l}\text { Oh } \\
\text { et al. }\end{array}$ & 2010 & $\begin{array}{l}\text { USA, } \\
\text { China }\end{array}$ & Mix & EAC & 52 & 7 & 0 & 641 & 195 & 13 & 0.675274 & $\mathrm{~N}$ & $\begin{array}{l}\text { Age, sex, ethnicity, } \\
\text { education, smoking, } \\
\text { and alcohol }\end{array}$ \\
\hline
\end{tabular}

${ }^{a}$ ESCC: esophageal squamous cell carcinoma, EAC: esophageal adenocarcinoma.

${ }^{\mathrm{b}} \mathrm{HWE}$, Hardy-Weinberg equilibrium, $\mathrm{P}>0.05$ indicates that the participants in control group met the HWE.

c "Y" indicates an association between TNF- $\alpha-308$ G/A polymorphism and risk of ESCC/EAC, "N" indicates no association between this SNP and ESCC/EAC.

\section{Meta-analysis of crude and adjusted data}

Among these 11 studies, all of the crude and adjusted data are available. The forest plots of different models and allele frequency are shown in Figure 2 (ESCC group) and Figure 3 (EAC group). The $\mathrm{I}^{2}$ value of heterogeneities remain in a low level for both crude and adjusted data. This indicates that the studies we included were homogeneous. In ESCC group, dominant model $(\mathrm{GA}+\mathrm{AA}$ vs $\mathrm{GG}): \mathrm{OR}_{\mathrm{adj}}=1.19(1.00,1.41)$, recessive model (AA vs $\mathrm{GG}+\mathrm{GA}$ ): $\mathrm{OR}_{\mathrm{adj}}=1.02(0.63$, $1.61)$, over-dominant model ( $G G$ vs $A A)$ : $\mathrm{OR}_{\text {adj }}=0.83$ $(0.70,0.99)$, and allele frequency $(\mathrm{G}$ vs $\mathrm{A}): \mathrm{OR}_{\mathrm{adj}}=0.88$ $(0.76,1.02)$. In EAC group, dominant model (GA+AA vs $G G): \mathrm{OR}_{\mathrm{adj}}=0.84(0.51,1.37)$, recessive model (AA vs $\mathrm{GG}+\mathrm{GA}): \mathrm{OR}_{\mathrm{adj}}=1.19(0.67,2.11)$, over-dominant model (GG vs AA): $\mathrm{OR}_{\mathrm{adj}}=1.17(0.76,1.81)$, and allele frequency $(\mathrm{G} v \mathrm{vs}): \mathrm{OR}_{\mathrm{adj}}=1.17(0.74,1.86)$. The detailed overall and stratified meta-analyses using crude and adjusted data are shown in Table 2. Meanwhile, the association between TNF- $\alpha-308 \mathrm{G} / \mathrm{A}$ polymorphism and other cancers is shown in Table 3.

\section{Sensitivity analysis}

The stability of the study was detected by "metaninf" module in STATA version 14.0 (STATA Corporation, College Station, TX, USA). The sensitivity analysis indicates that the results was stable. Because of the limited number of studies in EAC group, the analysis was only performed in ESCC group. In ESCC group, the results of sensitivity analysis are shown in Figure 4.

\section{Assessment of publication bias}

In EAC group, we did not assess the publication bias due to the limited number of studies. In ESCC group, the results did not show publication bias, and funnel plots are shown in Figure 5.

\section{DISCUSSION}

Our meta-analysis, which included 1855 cases and 3762 controls, assessed the association between rs 1800629 and the risk of EC. Our results indicate that rs1800629 is not significantly associated with an increase in the risk of EC. To achieve greater accuracy, pooled OR with $95 \%$ CI were calculated from the selected case-control studies based on both crude and adjusted data. Our results did not change in sensitivity analyses.

Cancer is a multifactor disease that can be caused by genetics, environment, lifestyle, and ethnicity. The frequencies of genetic polymorphisms often vary among ethnic groups. For the TNF- $\alpha-308 \mathrm{G} / \mathrm{A}$ polymorphism, the prevalence is $17 \%, 8 \%, 2 \%$, and $6 \%$ in European, Chinese Han, Japanese, and African ancestry groups, respectively, in southwestern USA populations (http://hapmap.ncbi.nlm. nih.gov). A previous study has shown that ethnic-specific differences were evident in the association of CASP8$6256 \mathrm{~N}$ del and D302H polymorphisms with prostate cancer risk in east Asian and Indian populations [25]. Liu et al. found that the risk of cardiovascular and endstage renal diseases in native Asian subjects with type 2 diabetes vary substantially among different ethnic groups 


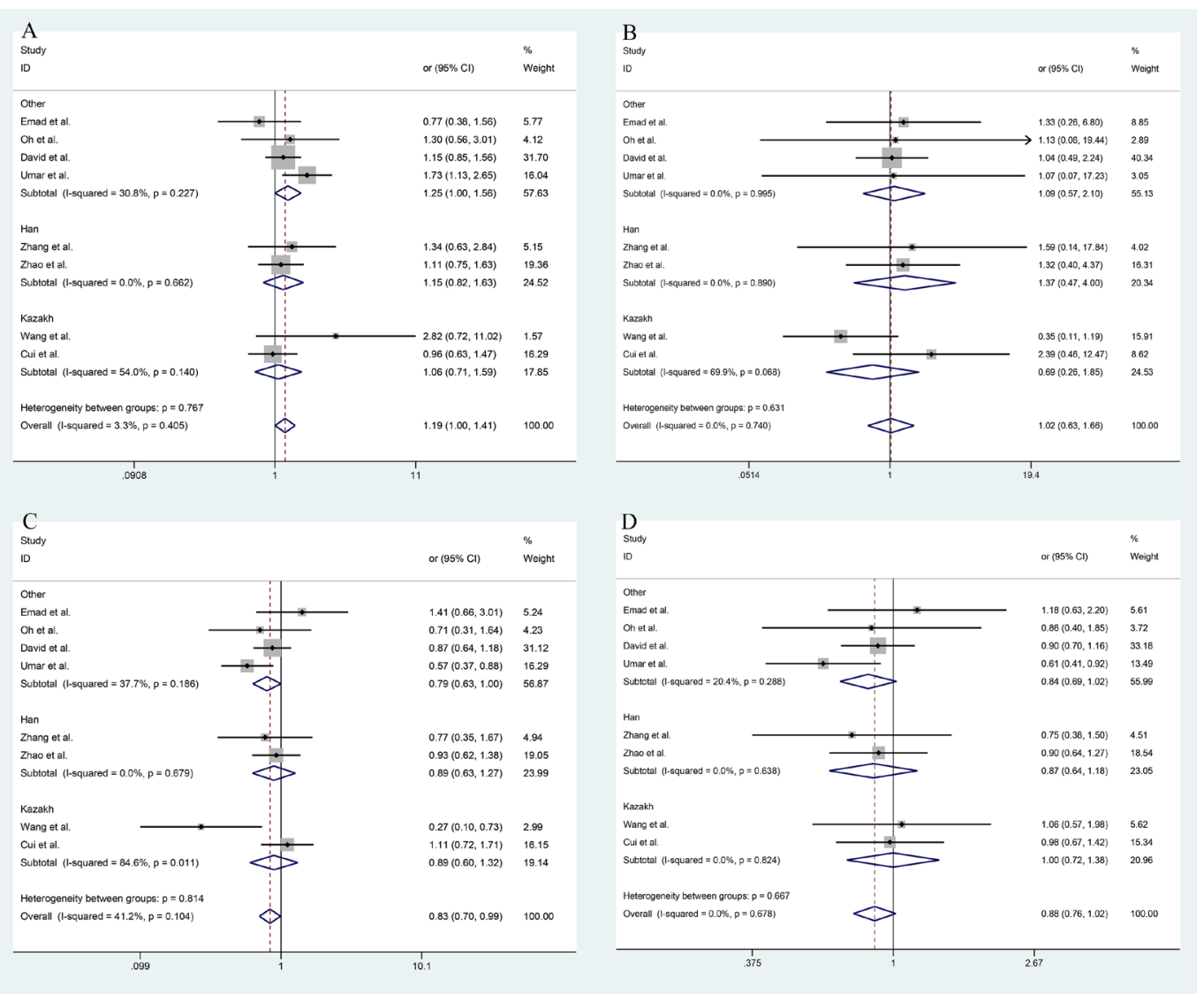

Figure 2: The forest plot of different model and allele frequency (ESCC group). A. dominant model; B. recessive model; C. over-dominant model; $\mathbf{D}$. allele frequency.

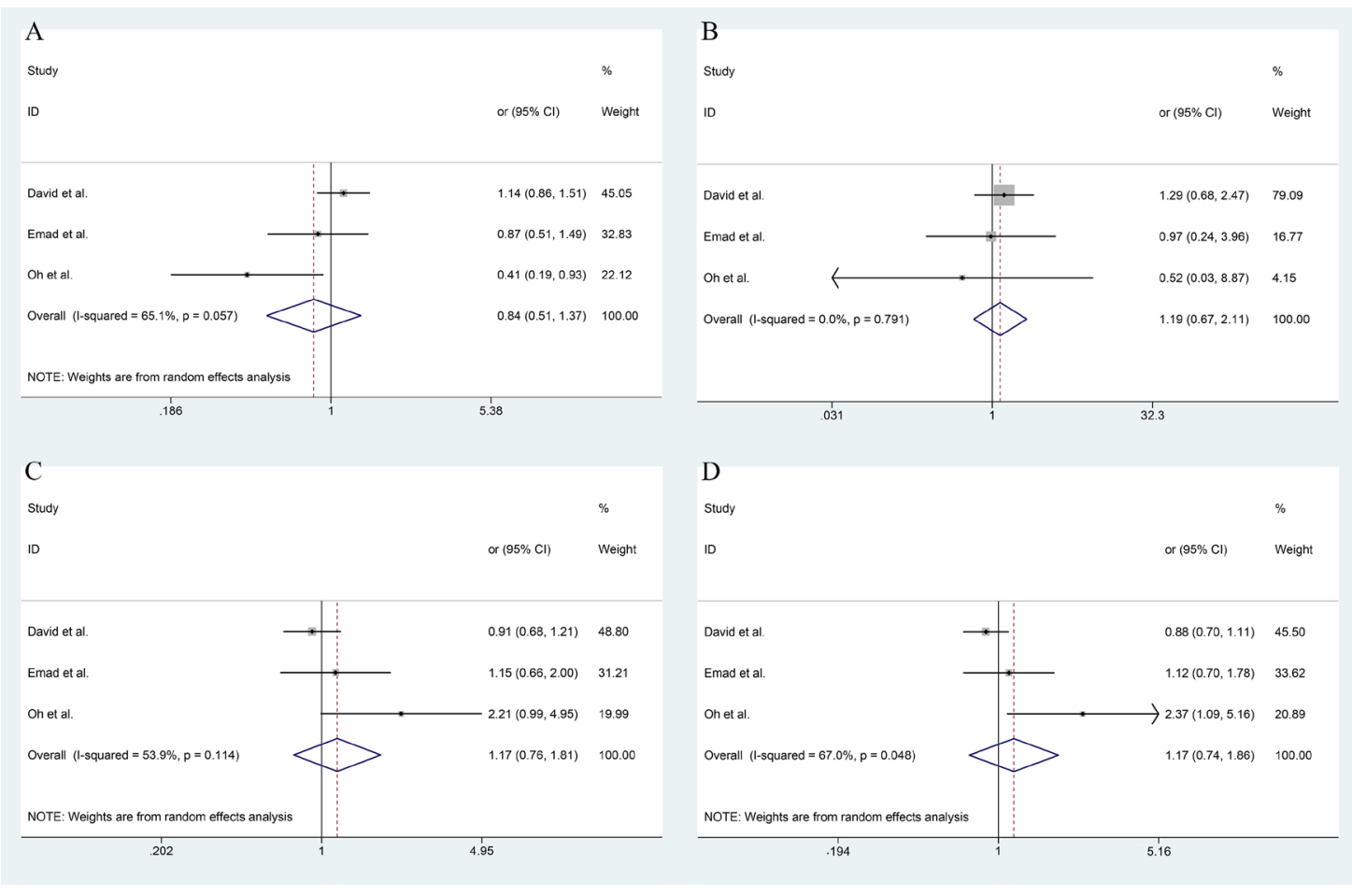

Figure 3: The forest plot of different model and allele frequency (EAC group). A. dominant model; B. recessive model; C. over-dominant model; $\mathbf{D}$. allele frequency. 
Table 2: Meta-analysis of the TNF- $\alpha-308 \mathrm{G}>\mathrm{A}$ polymorphism on ESCC and EAC group

\begin{tabular}{|c|c|c|c|c|c|c|c|c|c|c|}
\hline \multirow{2}{*}{ Group } & \multirow{2}{*}{ Comparison } & \multirow{2}{*}{ Population } & \multirow{2}{*}{$\begin{array}{c}\text { OR } \\
\text { (Crude) }\end{array}$} & \multirow{2}{*}{$\begin{array}{c}\text { OR } \\
\text { (Adjusted) }\end{array}$} & \multirow{2}{*}{$95 \% \mathrm{CI}$} & \multicolumn{3}{|c|}{ Test of association } & \multirow{2}{*}{ Model } & \multirow{2}{*}{$\begin{array}{l}\text { Heterogeneity } \\
\qquad \mathbf{I}^{2}\end{array}$} \\
\hline & & & & & & $P$ & $P(\mathrm{BON})$ & $P($ FDR $)$ & & \\
\hline \multirow{19}{*}{ ESCC } & \multirow{5}{*}{$\begin{array}{c}\mathrm{GA}+\mathrm{AA} \text { vs } \\
\mathrm{GG}\end{array}$} & Overall & 1.19 & 1.19 & $\begin{array}{l}1.00- \\
1.41\end{array}$ & 0.046 & 0.160 & 0.092 & $\mathrm{~F}$ & $3.3 \%$ \\
\hline & & Han & 1.15 & 1.15 & $\begin{array}{c}0.82- \\
1.63\end{array}$ & 0.662 & 1 & 0.662 & $\mathrm{~F}$ & $0.0 \%$ \\
\hline & & Kazakh* $^{*}$ & 1.06 & 1.06 & $\begin{array}{l}1.06- \\
0.71\end{array}$ & 0.780 & - & - & $\mathrm{F}$ & $54.0 \%$ \\
\hline & & Kazakh & 1.35 & 1.35 & $\begin{array}{l}0.51- \\
3.56\end{array}$ & 0.550 & 1 & 0.994 & $\mathrm{R}$ & $54.0 \%$ \\
\hline & & Other & 1.25 & 1.25 & $\begin{array}{l}1.00- \\
1.56\end{array}$ & 0.227 & 0.454 & 0.302 & $\mathrm{~F}$ & $30.8 \%$ \\
\hline & \multirow{5}{*}{$\begin{array}{c}\text { AA vs } \\
\text { GG+GA }\end{array}$} & Overall & 1.00 & 1.02 & $\begin{array}{c}0.63- \\
1.66\end{array}$ & 0.929 & 0.929 & 0.929 & $\mathrm{~F}$ & $0.0 \%$ \\
\hline & & Han & 1.37 & 1.37 & $\begin{array}{c}0.47- \\
4.00\end{array}$ & 0.569 & 1 & 0.662 & $\mathrm{~F}$ & $0.0 \%$ \\
\hline & & Kazakh* & 0.70 & 0.69 & $\begin{array}{c}0.26- \\
1.85\end{array}$ & 0.465 & - & - & $\mathrm{F}$ & $69.9 \%$ \\
\hline & & Kazakh & 0.85 & 0.85 & $\begin{array}{l}0.13- \\
5.44\end{array}$ & 0.860 & 1 & 0.994 & $\mathrm{R}$ & $69.9 \%$ \\
\hline & & Other & 1.09 & 1.09 & $\begin{array}{l}0.57- \\
2.10\end{array}$ & 0.794 & 0.794 & 0.794 & $\mathrm{~F}$ & $0.0 \%$ \\
\hline & \multirow{5}{*}{$\begin{array}{c}\mathrm{GG}+\mathrm{AA} \text { vs } \\
\mathrm{GA}\end{array}$} & Overall & 0.83 & 0.83 & $\begin{array}{c}0.70- \\
0.99\end{array}$ & 0.040 & 0.160 & 0.092 & $\mathrm{~F}$ & $41.2 \%$ \\
\hline & & Han & 0.89 & 0.89 & $\begin{array}{c}0.63- \\
1.27\end{array}$ & 0.520 & 1 & 0.662 & $\mathrm{~F}$ & $0.0 \%$ \\
\hline & & Kazakh $^{*}$ & 0.87 & 0.89 & $\begin{array}{c}0.60- \\
1.32\end{array}$ & 0.564 & - & - & $\mathrm{F}$ & $84.6 \%$ \\
\hline & & Kazakh & 0.59 & 0.59 & $\begin{array}{l}0.15- \\
2.35\end{array}$ & 0.453 & 1 & 0.994 & $\mathrm{R}$ & $84.6 \%$ \\
\hline & & Other & 0.80 & 0.79 & $\begin{array}{c}0.63- \\
1.00\end{array}$ & 0.049 & 0.196 & 0.166 & $\mathrm{~F}$ & $37.7 \%$ \\
\hline & \multirow{4}{*}{ G vs A } & Overall & 0.88 & 0.88 & $\begin{array}{c}0.76- \\
1.02\end{array}$ & 0.085 & 0.170 & 0.113 & $\mathrm{~F}$ & $0.0 \%$ \\
\hline & & Han & 0.87 & 0.87 & $\begin{array}{c}0.64- \\
1.18\end{array}$ & 0.377 & 1 & 0.662 & $\mathrm{~F}$ & $0.0 \%$ \\
\hline & & Kazakh & 1.00 & 1.00 & $\begin{array}{l}0.72- \\
1.02\end{array}$ & 0.994 & 1 & 0.994 & $\mathrm{~F}$ & $0.0 \%$ \\
\hline & & Other & 0.84 & 0.84 & $\begin{array}{c}0.69- \\
1.02\end{array}$ & 0.083 & 0.249 & 0.166 & $\mathrm{~F}$ & $20.4 \%$ \\
\hline \multirow{4}{*}{ EAC } & $\begin{array}{c}\mathrm{GA}+\mathrm{AA} \text { vs } \\
\mathrm{GG}\end{array}$ & Mix & 0.89 & 0.84 & $\begin{array}{c}0.51- \\
1.37\end{array}$ & 0.952 & 1 & 0.952 & $\mathrm{R}$ & $65.1 \%$ \\
\hline & $\begin{array}{c}\text { AA vs } \\
\text { GG+GA }\end{array}$ & Mix & 1.16 & 1.19 & $\begin{array}{l}0.67- \\
2.11\end{array}$ & 0.563 & 1 & 0.952 & $\mathrm{~F}$ & $0.0 \%$ \\
\hline & $\begin{array}{c}\mathrm{GG}+\mathrm{AA} \text { vs } \\
\mathrm{GA}\end{array}$ & Mix & 1.05 & 1.17 & $\begin{array}{c}0.76- \\
1.81\end{array}$ & 0.480 & 1 & 0.952 & $\mathrm{R}$ & $53.9 \%$ \\
\hline & G vs A & Mix & 1.02 & 1.17 & $\begin{array}{c}0.74- \\
1.86\end{array}$ & 0.879 & 1 & 0.952 & $\mathrm{R}$ & $67.0 \%$ \\
\hline
\end{tabular}

OR, odds ratio; $\mathbf{C I}$, confidence intervals; $\mathbf{R}$, random effects model; $\mathbf{F}$, fixed effects model; $\mathrm{P}(\mathrm{FDR}) p$ value from BenjaminiHochberg method; $\mathrm{P}(\mathrm{BON}) p$ value in stepdown Bonferroni testing; $\mathrm{T}$; the values marked with $\mathrm{a}$ * represent the results of the alternative approach (fixed effects despite heterogeneity) 
Table 3: The association between TNF-- $\alpha-308$ G/A polymorphism and other cancers

\begin{tabular}{|c|c|c|c|c|}
\hline Study & Cancer Type & Year & Ethnicity & Association $^{\mathrm{a}}$ \\
\hline Ming-Hsui Tsai et al. & Nasopharyngeal carcinoma & 2002 & Taiwanese & $\mathrm{N}$ \\
\hline Veljko Flego et al. & Lung Cancer & 2009 & Croatian & $\mathrm{N}$ \\
\hline Carola Seifart et al. & Lung Cancer & 2005 & Caucasian & $\mathrm{N}$ \\
\hline M. M. Stankovic et al. & Lung Cancer & 2008 & Not mentioned & $\mathrm{Y}$ \\
\hline Elvira Garza-Gonza'lez et al. & Gastric carcinoma & 2005 & Mexican & $\mathrm{N}$ \\
\hline Ming-Shiang WU et al. & Gastric carcinoma & 2004 & Chinese & $\mathrm{N}$ \\
\hline Chun Li et al. & Gastric carcinoma & 2005 & Chinese & $\mathrm{N}$ \\
\hline Ja Young Lee et al. & Gastric carcinoma & 2005 & Korean & $\mathrm{N}$ \\
\hline T. Yu et al. & Gastric cancer & 2014 & Chinese Han & $\mathrm{Y}$ \\
\hline Mitsushige Sugimoto et al. & Gastric cancer & 2007 & Japanese & $\mathrm{Y}$ \\
\hline Josecarlos Machado et al. & Gastric cancer & 2003 & Portuguese & $\mathrm{Y}$ \\
\hline Gareth J. Morgan et al. & Myeloma & 2005 & Englishman & $\mathrm{N}$ \\
\hline Lone Skov et al. & Basal cell carcinoma & 2003 & Caucasian & $\mathrm{N}$ \\
\hline Vandana A Govan et al. & Cervical cancer & 2006 & South African & $\mathrm{N}$ \\
\hline Ning Wang et al. & Cervical cancer & 2012 & Chinese & $\mathrm{N}$ \\
\hline Andrzej Roszak et al. & Cervical cancer & 2015 & Polish & $\mathrm{Y}$ \\
\hline Angela DeMichele et al. & Breast cancer & 2003 & American & $\mathrm{N}$ \\
\hline K. C. Smith et al. & Breast cancer & 2004 & Englishman & $\mathrm{N}$ \\
\hline Prithvi Kumar Singh et al. & Oral squamous cell carcinoma & 2015 & Indian & $\mathrm{N}$ \\
\hline Chung-Ji Liu et al. & Oral squamous cell carcinoma & 2005 & Taiwanese & $\mathrm{Y}$ \\
\hline Chuen-Ming Shih et al. & Oral cancer & 2005 & Chinese & $\mathrm{Y}$ \\
\hline Christos Yapijakis et al. & Oral cancer & 2009 & $\begin{array}{l}\text { Greek and } \\
\text { German }\end{array}$ & $\mathrm{Y}$ \\
\hline Nega Berhane et al. & Prostate cancer & 2012 & Indian & $\mathrm{Y}$ \\
\hline Bilkay Bas xtu“ rk et al. & Renal cell carcinoma & 2005 & Not mentioned & $\mathrm{Y}$ \\
\hline PILDU JEONG et al. & Bladder cancer & 2004 & Korean & $\mathrm{Y}$ \\
\hline Kathrin Seidemann et al. & Non-Hodgkin's Lymphoma & 2005 & $\begin{array}{l}\text { Austrian, } \\
\text { German and } \\
\text { Swiss }\end{array}$ & $\mathrm{Y}$ \\
\hline Ho SY et al. & Hepatocellular carcinoma & 2004 & Taiwanese & $\mathrm{Y}$ \\
\hline Penka N. Nikolova et al. & Malignant melanoma & 2007 & Caucasian & $\mathrm{Y}$ \\
\hline
\end{tabular}

a "Y" indicates an association between TNF- $\alpha-308$ G/A polymorphism and cancer risk, "N" indicates no association between this SNP and cancer risk. 
(Chinese, Malay, and Indian) [26]. Chu et al. found that the association of a genetic polymorphism with the risk of coronary artery disease varied among different ethnic groups (Chinese, Malay, and Indian) [27]. It is possible that this SNP is associated with different degrees of EC risk in different regions and under diverse environmental conditions.

The TNF- $\alpha-308$ G/A polymorphism (rs1800629) is located in the promoter region and is associated with increased TNF- $\alpha$ production [28]. TNF is a cytokine involved in systemic inflammation, and it is produced chiefly by immune cells (especially macrophages, dendritic cells, lymphocytes, and mast cells) as a transmembrane protein [29]. Deans et al. found the AA $\mathrm{TNF} \alpha 308$ genotype to be related to an adverse prognosis of gastro-oesophageal cancer. In contrast to the IL-6 and IL-10 genotypes, there is no association between TNF $\alpha$ polymorphisms and systemic inflammation [30]. It is therefore less likely that the reduced survival associated with this cytokine is related entirely to the generation of an inflammatory response.

The AA genotype of TNF- $\alpha-308$ can bind to two receptors in cellular responses: TNFR1 (TNF receptor type 1) and TNFR2 (TNF receptor type 2) [31]. Through these two distinct receptors, TNF can activate pathways leading to diverse cellular effects: cell survival, activation, differentiation, proliferation, and cell death. TNF can induce the expression of transforming growth factor alpha (TGF $\alpha$ ) and epidermal growth factor receptor (EGFR) in cancer cells [32-34]. This means TNF may have a role in the proliferation of cancer cells.

The TNF- $\alpha-308$ G/A polymorphism is an interesting SNP site. It has been reported to be associated with Cervical cancer, Gastric cancer, Oral cancer, Prostate cancer, Renal cell carcinoma, Bladder cancer, Hepatocellular carcinoma, Malignant melanoma and
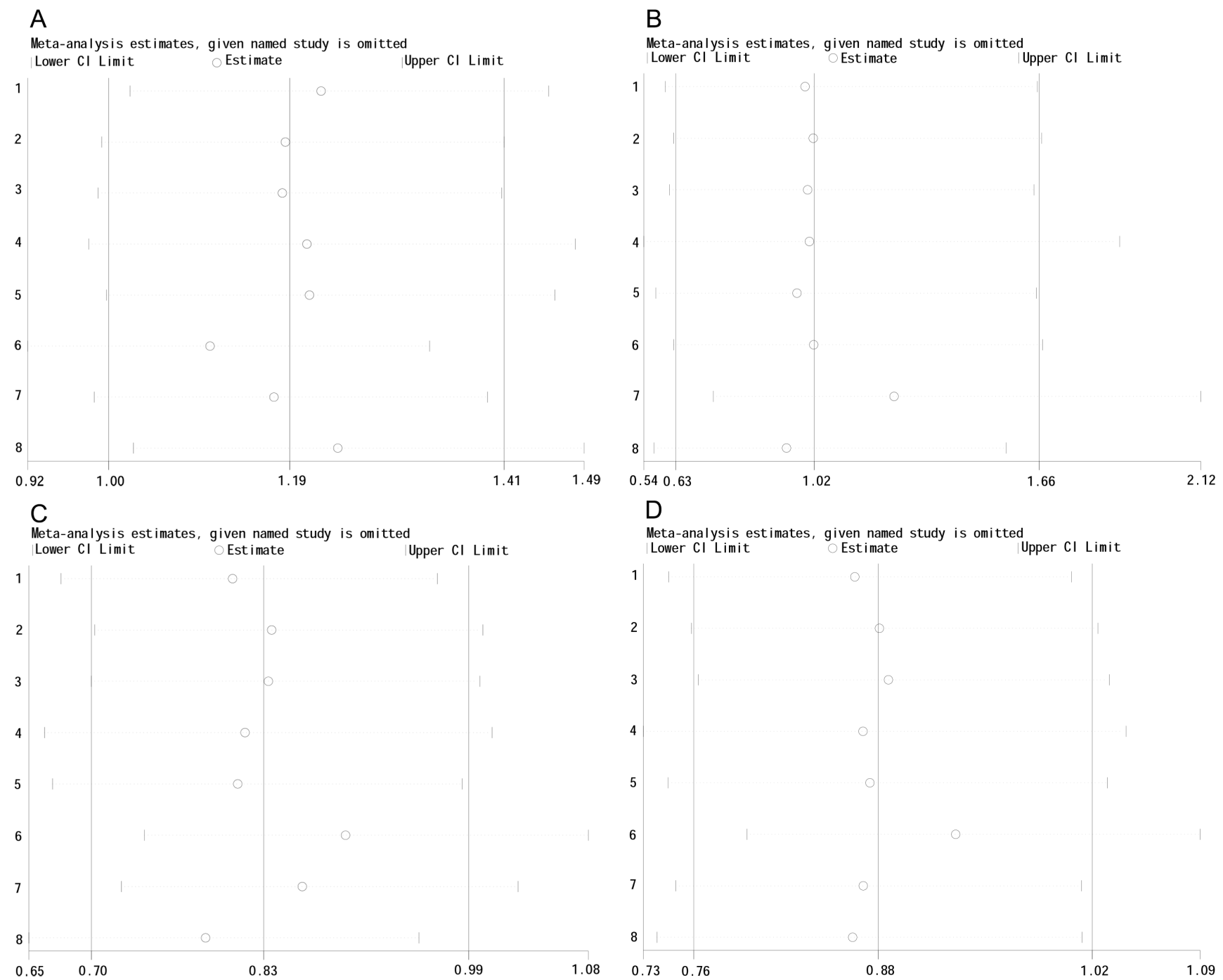

Figure 4: The sensitivity analysis in ESCC group. A. dominant model; B. recessive model; C. over-dominant model; D. allele frequency. 
Non-Hodgkin's Lymphoma [35-48]. However, no significant association was found for Nasopharyngeal carcinoma, Lung cancer, Gastric carcinoma, Myeloma, Basal cell carcinoma, Cervical cancer, Breast cancer and Oral squamous cell carcinoma [49-62]. The association between this polymorphism and these cancer risk can be found in Table 3. Among inflammatory cytokines, TNF $\alpha$ is not the only one that is not significantly associated with cancer risk. Other polymorphisms, such as the interleukin 10-1082 G/A polymorphism, have no association with cervical cancer [63], esophageal squamous cell carcinoma, or gastric cardiac adenocarcinoma risk [64]. Thus, there is no obvious association between the TNF- $\alpha-308$ G/A polymorphism and cancer risk. The controversial association between TNF- $\alpha-308$ G/A polymorphism and cancer still needs to be confirmed.

With the development of high-throughput sequencing, the need for knowledge to assist precision medicine is increasing. In the era of precision medicine, a negative result has important implications. For a specific disease, a negative result can help us filter out the noise variant from all of the sequencing data.
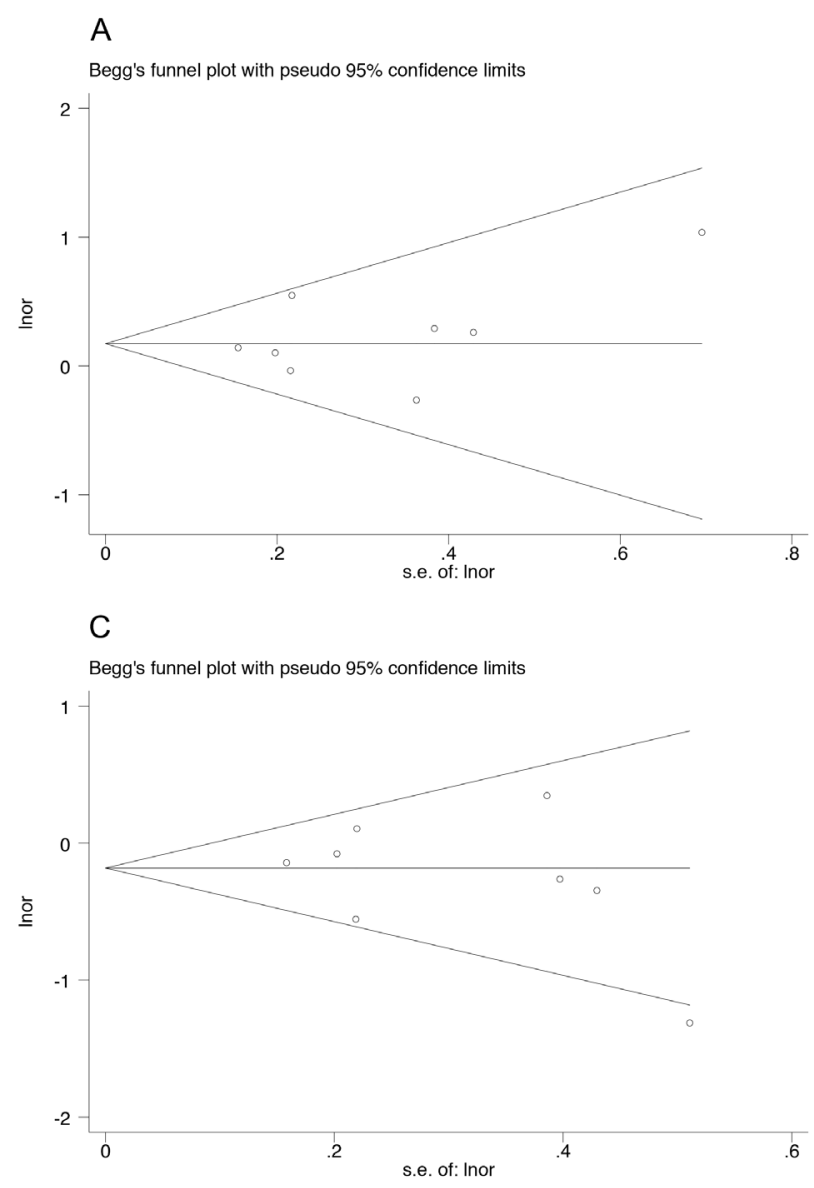

Several limitations should be taken into consideration. First, all included studies were published in English or Chinese. Studies published in other languages were not included, and the annual incidence rates of EC have been decreasing in recently years [65]. In other words, the number of patients with esophageal cancer is decreasing. Meanwhile, there might have unpublished negative studies that we cannot include in our analysis. Therefore, the conclusion of the null association between rs1800629 and EC might be weakened by the small sample size and publication bias. Second, heterogeneity was obvious in some groups in the sub-group analysis. However, the results did not change in a sensitivity analysis. Finally, this polymorphism may have a combinational effect of a SNP-SNP interaction on the EC risk; however, we cannot estimate this from the data reported by the included original studies.

In conclusion, our meta-analysis shows that TNF- $\alpha-308 \quad \mathrm{G}>\mathrm{A} \quad(\mathrm{rs} 1800629)$ is not significantly associated with an increased esophageal cancer risk. For genetic association studies, negative results of metaanalysis have a high level of evidence, and thus, our
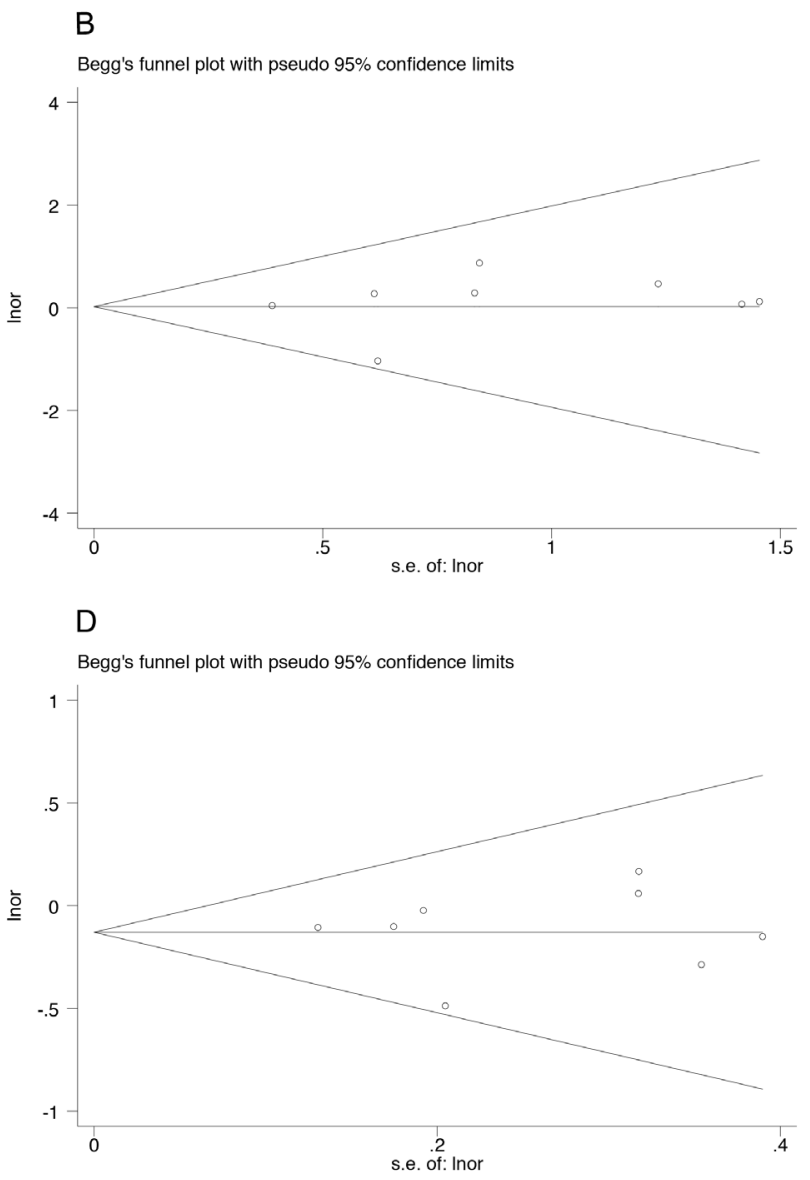

Figure 5: The funnel plot of different model and allele frequency (ESCC group). A. dominant model; B. recessive model; C. over-dominant model; D. allele frequency. 
results have special importance in the era of sequencingbased precision medicine. However, given the limitations of this meta-analysis, it is necessary to perform further experiments with more participants to confirm our conclusion.

\section{MATERIALS AND METHODS}

\section{Search strategy}

PubMed, Embase, Web of Science and CNKI database were searched by using the keywords "TNF $\alpha$ [MeSH]" and "esophageal cancer [MeSH]" for all studies published up to August 24, 2016. Studies that investigate the association between rs 1800629 and risk of esophageal cancer were included in this meta-analysis.

\section{Criterion for study selection}

The following inclusion criteria were set and reviewed by two independent investigators: (1) an independent case-control design, (2) evaluating the association between rs1800629 and risk of EC, (3) providing the number of genotypes in case-control groups for calculating odds ratio (OR) with $95 \%$ confidential intervals (CIs), and (4) genotypes of participants in control groups satisfy Hardy-Weinberg equilibrium (HWE).

\section{Data extraction}

Two independent reviewers collected data from studies included in the meta-analysis. The following data were included: first author, publication date, country, ethnicity of the study participants, type of esophageal cancer, number of genotypes in case-control groups and the association between rs1800629 and EC. In addition, $P$ value of Hardy-Weinberg equilibrium in control group was calculated to evaluate whether the sample in control groups comes from the same Mendel groups where allele and genotype frequencies in a population will remain constant from generation to generation in the absence of other evolutionary influences.

\section{Statistical analyses}

The association between the rs1800629 and EC risk was measured by Stata 12.0 to calculate the odds ratio (OR) with 95\% confidence intervals (CIs). The Chisquared test and Higgins's $\left(\mathrm{I}^{2}\right)$ test were used to assess heterogeneity. We used the fixed effects model to combine the data if $\mathrm{I}^{2}<50 \%$ or the $P$-value of heterogeneity was $>0.10$. Otherwise, the random effects model was chosen. Pooled OR with 95\% CI were calculated for casecontrol studies based on both crude and adjusted data for the selected studies. For the crude data analysis, we used the number of people with or without esophageal cancer in the case and control group. For the analysis of the adjusted data, we extracted the OR with 95\% CI that had been adjusted for various potential confounders [66]. The Z-test was used to determine the significance of the overall $\mathrm{OR}$, and $P<0.05$ was considered statistically significant. In order to adjust for multiple comparisons, we used the Benjamini-Hochberg $(\mathrm{BH})$ method and stepdown Bonferroni method, which control for false discovery rate (FDR) and familywise error rate (FWE), respectively. The sensitivity analysis was measured by "metaninf" module. The Begg's rank correlation test and Egger's linear regression test were used to assess the publication bias, and $P<0.05$ was considered statistically significant. All statistical analyses were conducted by STATA version 14.0 (STATA Corporation, College Station, TX, USA) and $\mathrm{R}$ package version 3.2.3.

\section{ACKNOWLEDGMENTS}

The authors gratefully acknowledge the Natural Science Foundation of Hubei Provincial Department of Education (grant number: Q20162115); Shiyan Taihe Hospital youth team project (grants number: 2006TD008, 2012TD01); The Key Discipline Project of Hubei Province (grant number: 2012ZDFX04); Shanghai Zhanjiang major projects development (grant number: ZJ2015-ZD-003).

\section{CONFLICTS OF INTEREST}

The authors declare that they have no competing interest.

\section{REFERENCES}

1. Yang X, Zhu H, Qin Q, Yang Y, Yang Y, Cheng H and Sun $X$. Genetic variants and risk of esophageal squamous cell carcinoma: a GWAS-based pathway analysis. Gene. 2015; 556:149-152.

2. Liu HB, Yang QC, Shen Y, Zhu Y, Zhang XJ and Chen H. A disintegrin and metalloproteinase $17 \mathrm{mRNA}$ and protein expression in esophageal squamous cell carcinoma, as well as its clinicopathological factors and prognosis. Molecular medicine reports. 2015; 11:961-967.

3. Liu H, Zhu Y, Yang Q, Shen Y, Zhang X and Chen H. Expression and clinical significance of ADAM17 protein in esophageal squamous cell carcinoma. Genetics and molecular research. 2015; 14:4391.

4. Arnal MJD, Arenas ÁF and Arbeloa ÁL. Esophageal cancer: Risk factors, screening and endoscopic treatment in Western and Eastern countries. World journal of gastroenterology. 2015; $21: 7933$.

5. Siegel RL, Miller KD and Jemal A. Cancer statistics, 2016. Cancer J Clin. 2016; 62:10-29.

6. Abnet CC, Freedman ND, Hu N, Wang Z, Yu K, Shu X-O, Yuan J-M, Zheng W, Dawsey SM and Dong LM. A shared susceptibility locus in PLCE1 at 10q23 for gastric 
adenocarcinoma and esophageal squamous cell carcinoma. Nature genetics. 2010; 42:764-767.

7. Wu C, Hu Z, He Z, Jia W, Wang F, Zhou Y, Liu Z, Zhan Q, Liu Y and Yu D. Genome-wide association study identifies three new susceptibility loci for esophageal squamous-cell carcinoma in Chinese populations. Nature genetics. 2011; 43:679-684.

8. Kirkpatrick A, Bidwell J, Van den Brule A, Meijer C, Pawade $\mathrm{J}$ and Glew S. TNF $\alpha$ polymorphism frequencies in HPV-associated cervical dysplasia. Gynecologic oncology. 2004; 92:675-679.

9. Esposito E and Cuzzocrea S. TNF-alpha as a therapeutic target in inflammatory diseases, ischemia-reperfusion injury and trauma. Current medicinal chemistry. 2009; 16:3152-3167.

10. Wilson AG, Symons JA, McDowell TL, McDevitt HO and Duff GW. Effects of a polymorphism in the human tumor necrosis factor $\alpha$ promoter on transcriptional activation. Proceedings of the National Academy of Sciences. 1997; 94:3195-3199.

11. Kroeger KM, Carville KS and Abraham LJ. The - 308 tumor necrosis factor- $\alpha$ promoter polymorphism effects transcription. Molecular immunology. 1997; 34:391-399.

12. Locksley RM, Killeen $\mathrm{N}$ and Lenardo MJ. The TNF and TNF receptor superfamilies: integrating mammalian biology. Cell. 2001; 104:487-501.

13. Dowlati Y, Herrmann N, Swardfager W, Liu H, Sham L, Reim EK and Lanctôt KL. A meta-analysis of cytokines in major depression. Biological psychiatry. 2010; 67:446-457.

14. Swardfager W, Lanctôt K, Rothenburg L, Wong A, Cappell J and Herrmann N. A meta-analysis of cytokines in Alzheimer's disease. Biological psychiatry. 2010; 68:930-941.

15. Victor F and Gottlieb A. TNF-alpha and apoptosis: implications for the pathogenesis and treatment of psoriasis. Journal of drugs in dermatology. 2002; 1:264-275.

16. Brynskov J, Foegh P, Pedersen G, Ellervik C, Kirkegaard T, Bingham A and Saermark T. Tumour necrosis factor $\alpha$ converting enzyme (TACE) activity in the colonic mucosa of patients with inflammatory bowel disease. Gut. 2002; 51:37-43.

17. El-Omar EM, Rabkin CS, Gammon MD, Vaughan TL, Risch HA, Schoenberg JB, Stanford JL, Mayne ST, Goedert J and Blot WJ. Increased risk of noncardia gastric cancer associated with proinflammatory cytokine gene polymorphisms. Gastroenterology. 2003; 124:1193-1201.

18. Oh SS, Chang SC, Cai L, Cordon - Cardo C, Ding BG, Greenland S, He N, Jiang Q, Kheifets L and Le A. Single nucleotide polymorphisms of 8 inflammation - related genes and their associations with smoking - related cancers. International Journal of Cancer. 2010; 127:2169-2182.

19. Whiteman DC, Parmar P, Fahey P, Moore SP, Stark M, Zhao ZZ, Montgomery GW, Green AC, Hayward NK and Webb PM. Association of Helicobacter pylori infection with reduced risk for esophageal cancer is independent of environmental and genetic modifiers. Gastroenterology. 2010; 139:73-83.

20. Lingling Z. (2010). Association of G-308A tumor necrosis factor alpha gene polymorphism with prognosis esophageal squamous cell carcinoma. Hebei Medical University).

21. Wen-peng Z, Zhan-hui M, Ping L and Fen X. Correlation of TNF- $\alpha$ polymorphism and Esophageal Squamous Cell Carcinoma. National Medical Frontiers of China. 2010; 5:6-8.

22. Cui X-B, Wang D-D, Zhang H-Y, Li T-T, Jin T-T, Peng H, Zhang S-M, Wang B, Yu J and Liu C-X. Tumor necrosis factor- $\alpha$ gene $308 \mathrm{G} / \mathrm{A}$ polymorphism is not associated with esophageal squamous cell carcinoma risk in Kazakh patients. International journal of clinical and experimental pathology. 2015; 8:9293.

23. Umar M, Upadhyay R, Kumar S, Ghoshal UC and Mittal B. Association of common polymorphisms in TNFA, NFkB1 and NFKBIA with risk and prognosis of esophageal squamous cell carcinoma. PloS one. 2013; 8:e81999.

24. Hai-feng W, Hong-bo L, Hare A, Apizi PL and Abulimiti Y. p21 and TNF- $\alpha$ gene polymorphisms and susceptibility of Xinjiang Kazakh esophageal family. Chin J Cancer Prev Treat. 2014; 21:329-332.

25. Zhang C-D, Li H-T, Liu K, Lin Z-D, Peng Q-L, Qin X, He M, Wu H, Mo Z-N and Yang X-L. Impact of Caspase-8 (CASP8)-652 6N Del and D302H Polymorphisms on Prostate Cancer in Different Ethnic Groups. Asian Pacific Journal of Cancer Prevention. 2014; 15:7713-7718.

26. Liu J, Lim S, Yeoh L, Su C, Tai B, Low S, Fun S, Tavintharan S, Chia K and Tai E. Ethnic disparities in risk of cardiovascular disease, end - stage renal disease and all - cause mortality: a prospective study among Asian people with Type 2 diabetes. Diabetic Medicine. 2015.

27. Chu WC, Aziz AFA, Nordin AJ and Cheah YK. Association of Cholesteryl Ester Transfer Protein and Endothelial Nitric Oxide Synthase Gene Polymorphisms With Coronary Artery Disease in the Multi-Ethnic Malaysian Population. Clinical and Applied Thrombosis/Hemostasis. 2015:1076029615571628.

28. Jang WH, Yang Y-I, Yea SS, Lee YJ, Chun JH, Kim H-I, Kim MS and Paik K-H. The-238 tumor necrosis factor- $\alpha$ promoter polymorphism is associated with decreased susceptibility to cancers. Cancer letters. 2001; 166:41-46.

29. Waters JP, Pober JS and Bradley JR. Tumour necrosis factor and cancer. The Journal of pathology. 2013; 230:241-248.

30. Deans C, Rose-Zerilli M, Wigmore S, Ross J, Howell M, Jackson A, Grimble R and Fearon K. Host cytokine genotype is related to adverse prognosis and systemic inflammation in gastro-oesophageal cancer. Annals of surgical oncology. 2007; 14:329-339.

31. Theiss AL, Simmons JG, Jobin C and Lund PK. Tumor necrosis factor (TNF) $\alpha$ increases collagen accumulation and proliferation in intestinal myofibroblasts via TNF 
receptor 2. Journal of Biological Chemistry. 2005; 280:36099-36109.

32. Schmiegel W, Roeder C, Schmielau J, Rodeck U and Kalthoff H. Tumor necrosis factor alpha induces the expression of transforming growth factor alpha and the epidermal growth factor receptor in human pancreatic cancer cells. Proceedings of the National Academy of Sciences. 1993; 90:863-867.

33. Kalthoff H, Roeder C, Brockhaus M, Thiele H-G and Schmiegel W. Tumor necrosis factor (TNF) up-regulates the expression of p75 but not p55 TNF receptors, and both receptors mediate, independently of each other, up-regulation of transforming growth factor alpha and epidermal growth factor receptor mRNA. Journal of Biological Chemistry. 1993; 268:2762-2766.

34. Al-Lamki RS, Sadler TJ, Wang J, Reid MJ, Warren AY, Movassagh M, Lu W, Mills IG, Neal DE and Burge J. Tumor necrosis factor receptor expression and signaling in renal cell carcinoma. The American journal of pathology. 2010; 177:943-954.

35. Yu T, Lu Q, Ou X, Cao D and Yu Q. Clinical study on gastric cancer susceptibility genes IL-10-1082 and TNF- $\alpha$. Genet Mol Res. 2014; 13:10909-10912.

36. Sugimoto M, Furuta T, Shirai N, Nakamura A, Xiao F, Kajimura M, Sugimura H and Hishida A. Different effects of polymorphisms of tumor necrosis factor - alpha and interleukin - 1 beta on development of peptic ulcer and gastric cancer. Journal of gastroenterology and hepatology. 2007; 22:51-59.

37. Machado JC, Figueiredo C, Canedo P, Pharoah P, Carvalho R, Nabais S, Alves CC, Campos ML, Caldas C and Seruca R. A proinflammatory genetic profile increases the risk for chronic atrophic gastritis and gastric carcinoma. Gastroenterology. 2003; 125:364-371.

38. Roszak A, Misztal M, Sowińska A and Jagodziński PP. TNF- $\alpha-308$ G/A as a Risk Marker of Cervical Cancer Progression in the Polish Population. Molecular diagnosis \& therapy. 2015; 19:53-57.

39. Berhane N, Sobti RC, Melesse S, Mahdi SA and Kassu A. Significance of Tumor Necrosis factor $\alpha-308$ (G/A) gene polymorphism in the development of prostate cancer. Molecular biology reports. 2012; 39:11125-11130.

40. Yapijakis C, Serefoglou Z, Vylliotis A, Nkenke E, Derka S, Vassiliou S, Avgoustidis D, Neukam FW, Patsouris E and Vairaktaris E. Association of polymorphisms in Tumor Necrosis Factor Alpha and Beta genes with increased risk for oral cancer. Anticancer research. 2009; 29:2379-2386.

41. Liu CJ, Wong YK, Chang KW, Chang HC, Liu HF and Lee YJ. Tumor necrosis factor - $\alpha$ promoter polymorphism is associated with susceptibility to oral squamous cell carcinoma. Journal of oral pathology \& medicine. 2005; 34:608-612.

42. NAGORNI L, OBRADOVIC MM and MILIKIC DR. TNF$\alpha-308$ promotor polymorphism in patients with chronic obstructive pulmonary disease and lung cancer. Neoplasma. 2009; 56:4.

43. Shih C-M, Lee Y-L, Chiou H-L, Chen W, Chang G-C, Chou $\mathrm{M}-\mathrm{C}$ and Lin L-Y. Association of TNF- $\alpha$ polymorphism with susceptibility to and severity of non-small cell lung cancer. Lung cancer. 2006; 52:15-20.

44. Baştürk B, Yavaşçaoğlu İ, Vuruşkan H, Göral G, Oktay B and Oral HB. Cytokine gene polymorphisms as potential risk and protective factors in renal cell carcinoma. Cytokine. 2005; 30:41-45.

45. Jeong P, Kim E-J, Kim E-G, Byun S-S, Kim CS and Kim W-J. Association of bladder tumors and GA genotype of308 nucleotide in tumor necrosis factor-alpha promoter with greater tumor necrosis factor-alpha expression. Urology. 2004; 64:1052-1056.

46. Seidemann K, Zimmermann M, Book M, Meyer U, Burkhardt B, Welte K, Reiter A and Stanulla M. Tumor necrosis factor and lymphotoxin alfa genetic polymorphisms and outcome in pediatric patients with non-Hodgkin's lymphoma: results from Berlin-FrankfurtMünster Trial NHL-BFM 95. Journal of clinical oncology. 2005; 23:8414-8421.

47. Ho S-Y, Wang Y-J, Chen H-L, Chen C-H, Chang C-J, Wang P-J, Chen HH and Guo H-R. Increased risk of developing hepatocellular carcinoma associated with carriage of the TNF2 allele of the -308 tumor necrosis factor- $\alpha$ promoter gene. Cancer Causes \& Control. 2004; 15:657-663.

48. Nikolova PN, Pawelec GP, Mihailova SM, Ivanova MI, Myhailova AP, Baltadjieva DN, Marinova DI, Ivanova SS and Naumova EJ. Association of cytokine gene polymorphisms with malignant melanoma in Caucasian population. Cancer Immunology, Immunotherapy. 2007; 56:371-379.

49. Flego V, Badovinac AR, Bulat-Kardum L, Matanic D, Crnic-Martinovic M, Kapovic M and Ristic S. Primary lung cancer and TNF-alpha gene polymorphisms: a case-control study in a Croatian population. Medical Science Monitor Basic Research. 2009; 15:CR361-CR365.

50. Seifart C, Plagens A, Dempfle A, Clostermann U, Vogelmeier C, von Wichert P and Seifart U. TNF- $\alpha$, TNF$\beta$, IL-6, and IL-10 polymorphisms in patients with lung cancer. Disease markers. 2005; 21:157-165.

51. Tsai MH, Chen WC and Tsai FJ. Correlation of p21 gene codon 31 polymorphism and TNF - $\alpha$ gene polymorphism with nasopharyngeal carcinoma. Journal of clinical laboratory analysis. 2002; 16:146-150.

52. Garza - González E, Bosques - Padilla FJ, El - Omar E, Hold G, Tijerina - Menchaca R, Maldonado - Garza HJ and Pérez - Pérez GI. Role of the polymorphic IL - 1B, IL $1 \mathrm{RN}$ and TNF - A genes in distal gastric cancer in Mexico. International journal of cancer. 2005; 114:237-241.

53. Wu MS, Chen LT, Shun CT, Huang SP, Chiu HM, Wang HP, Lin MT, Cheng AL and Lin JT. Promoter polymorphisms of tumor necrosis factor $-\alpha$ are associated with risk of 
gastric mucosa-associated lymphoid tissue lymphoma. International journal of cancer. 2004; 110:695-700.

54. Li C, Xia B, Yang Y, Li J and Xia HH-X. TNF gene polymorphisms and Helicobacter pylori infection in gastric carcinogenesis in Chinese population. The American journal of gastroenterology. 2005; 100:290-294.

55. Lee JY, Kim HY, Kim KH, Kim SM, Jang MK, Park JY, Lee JH, Kim J-H and Yoo JY. Association of polymorphism of IL-10 and TNF-A genes with gastric cancer in Korea. Cancer letters. 2005; 225:207-214.

56. Morgan GJ, Adamson PJ, Mensah FK, Spink CF, Law GR, Keen LJ, Roman E, Davies FE, Rollinson S and Child J. Haplotypes in the tumour necrosis factor region and myeloma. British journal of haematology. 2005; 129:358-365.

57. Skov L, Allen MH, Bang B, Francis D, Barker JN and Baadsgaard O. Basal cell carcinoma is associated with high TNF - $\alpha$ release but not with TNF - $\alpha$ polymorphism at position- 308. Experimental dermatology. 2003; 12:772-776.

58. Govan VA, Constant D, Hoffman M and Williamson A-L. The allelic distribution of -308 Tumor Necrosis Factoralpha gene polymorphism in South African women with cervical cancer and control women. BMC Cancer. 2006; 6:1-6.

59. Wang N, Yin D, Zhang S, Wei H, Wang S, Zhang Y, Lu Y, Dai S, Li W and Zhang Q. TNF-alpha rs1800629 polymorphism is not associated with HPV infection or cervical cancer in the Chinese population. PLoS One. 2012; 7:e45246.

60. DeMichele A, Martin A-M, Mick R, Gor P, Wray L, Klein-Cabral M, Athanasiadis G, Colligan T, Stadtmauer
$\mathrm{E}$ and Weber B. Interleukin-6- 174G $\rightarrow \mathrm{C}$ polymorphism is associated with improved outcome in high-risk breast cancer. Cancer research. 2003; 63:8051-8056.

61. Smith K, Bateman A, Fussell H and Howell W. Cytokine gene polymorphisms and breast cancer susceptibility and prognosis*. European journal of immunogenetics. 2004; 31:167-173.

62. Singh PK, Bogra J, Chandra G, Ahmad MK, Gupta R, Kumar V, Jain A and Ali Mahdi A. Association of TNF- $\alpha$ (-238 and-308) promoter polymorphisms with susceptibility of oral squamous cell carcinoma in North Indian population. Cancer Biomarkers. 2015; 15:125-131.

63. Ni J, Ye Y, Teng F and Wu Q. Interleukin 10 polymorphisms and cervical cancer risk: a meta-analysis. International Journal of Gynecological Cancer. 2013; 23:126-133.

64. WeiGuo, NaWang, Yi-MinWang, YanLi, Deng-GuiWen, Zhi-FengChen, Yu-TongHe and Jian-HuiZhang. Interleukin-10 -1082 promoter polymorphism is not associated with susceptibility to esophageal squamous cell carcinoma and gastric cardiac adenocarcinoma in a population of high-incidence region of north China. World Journal of Gastroenterology. 2005; 11:858-862.

65. Chen W, Zheng R, Baade PD, Zhang S, Zeng H, Bray F, Jemal A, Yu XQ and He J. Cancer statistics in China, 2015. Cancer J Clin. 2016; 66:115-132.

66. Tian W, Zhao Y, Liu S and Li X. Meta-analysis on the relationship between nonsteroidal anti-inflammatory drug use and gastric cancer. European journal of cancer prevention. 2010; 19:288-298. 